(4) In both sheep and beef brain lecithin the amount of choline nitrogen is about equal to the amino alcohol nitrogen, the two comprising $85 \%$ of the total nitrogen in the lecithin.

(5) The other $15 \%$ is in the form of an unydrolyzable residue.

(6) If lecithin is a single substance, and it probably is not, or at least a much more complex one than is usually believed, it probably contains one molecule of each of the nitrogenous bases, choline and amino ethyl alcohol. This associated lecithin molecule is rather firmly combined with a saturated nitrogenous substance which it has been impossible, as yet, to remove.

LOS ANGRLES, CAL.

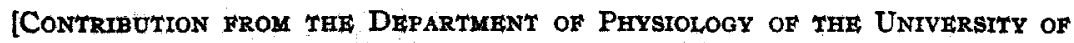
Chicago, The Memorlal, Instrtute of Infhetrous Disfashes, and Rush Medical College, Chicago.]

\title{
THE EFFECTS OF COMMERCIAL GLUCOSE WHEN FRD TO WHITE RATS.
}

By A. J. Careson, L. Hektohn and E. R. LeCount.

Received February 12, 1916.

In order to study the general effects of commercial glucose when consumed regularly in considerable quantities for a relatively long period of time, young white rats were fed over a period of six months with bread containing a certain amount of glucose. The white rat was selected because it is an easily handled, omnivorous animal whose average span of life covers about three years. For purposes of control another set of rats was fed on bread containing a certain amount of granulated cane sugar and a third set on bread without sugar.

The bread, which was unleavened, consisted of flour, rooo parts; lard, 25 parts; baking soda, I5 parts; hydrochloric acid, enough to neutralizethe soda; water as required for flour, about 655 parts; commercial glucose, 34 parts, in the case of "Glucose Bread," and granulated cane sugar, 26.5 parts, in the case of "Cane Sugar Bread." Fresh lots of the three kinds of bread were baked each Wednesday and Saturday.

In the laboratory in which the experiment took place, white rats are fed on white bread (baker's) about seven days old, small quantities of carrots, and occasionally a little meat. Fresh water is supplied each day. Careful special observations showed that 25 rats of the average weight of $75 \mathrm{~g}$. would eat $275 \mathrm{~g}$. of bread and $\mathrm{r} 7 \mathrm{o} \mathrm{g}$. of carrots a day. On the basis of these results and of the general experience, the feeding experiment was conducted with young rats, 25 in each cage, and a daily ration for each cage, to begin with, of $300 \mathrm{~g}$. of bread, i2 g. per rat, r 50 g. of carrots or other vegetables, or of meat occasionally, and plenty of 
water, all remnants of food being removed and a new supply put in at a certain time each day.

Accordingly, the experiment was started in the early part of April, 1915, with 200 young rats obtained from the Wistar Institute of Anatomy and Biology in Philadelphia during the previous month.

The rats were received in four lots of 50 . Lot I being born between the first and fourth of February, Lot 2 between the first and eighth, Lot 3 between the first and the tenth, and Lot 4 between the eleventh and eighteenth. The average weight of the animals March 29 varied from $70 \mathrm{~g}$. in the case of the oldest lot to $57.6 \mathrm{~g}$. in the case of the youngest. It should be stated here that in each lot were several rats which were smaller and which grew less than the others ("stunts," "runts").

For the purpose of the experiment each lot was divided into two groups, as nearly as possible of the same weight and proportion as to sex, of 25 each, which were caged separately in galvanized iron cages of the same size and construction; the cages were cleaned regularly and kept in a large well ventilated room in which there were no other animals.

The designation of each group, the kind of bread fed to each group, and the average weight on April 9 are shown in Table $I$.

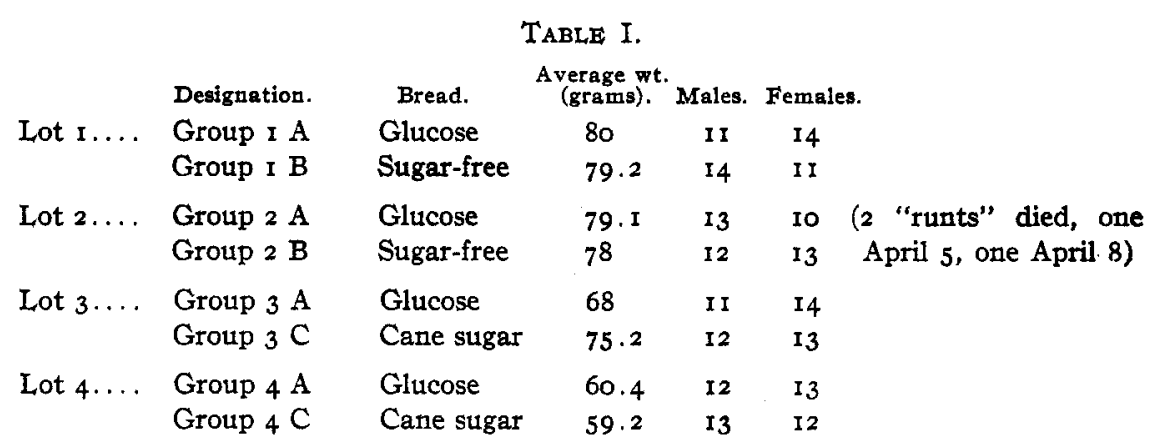

In other words, four groups of 25 rats each were put on glucose bread, two groups on sugar-free bread, and two groups on cane sugar bread. It was thought that this subdivision would offer a good chance for well controlled experiments with different kinds of bread under similar conditions for the different lots as received from Philadelphia.

Whenever a female rat gave indications of being pregnant, it was placed by itself on the same ration, proportionately, as before. As soon as the conditions allowed it, such rats were returned each to its group. So far as possible a record was kept of the number of young born in each group. As rats sometimes eat their young and as it may be difficult to detect that a rat is pregnant, this record of the number of young is not absolutely correct. 
Sick or untidy rats were isolated in large glass bowls and given a double ration of carrots. They were returned to their group only after complete recovery.

The rats did not escape infections, and during the course of the experiment a number of spontaneous deaths occurred, mostly from pneumonic infection and possibly also from so-called rat typhoid. These infections occurred in all the groups and did not affect the groups fed a certain kind of bread more severely than the other groups.

On May 12 the bread ration was increased to $16 \mathrm{~g}$. per day per rat; on August 23 the carrot ration was increased to $15 \mathrm{~g}$. per rat and day; no other change was made in the food. As a rule the day's supply was wholly consumed at the end of 24 hours with the exception of the hardest of the bread crusts.

The total weight of each group was determined every two weeks and the average weight per rat computed (see Table II and curves). In no

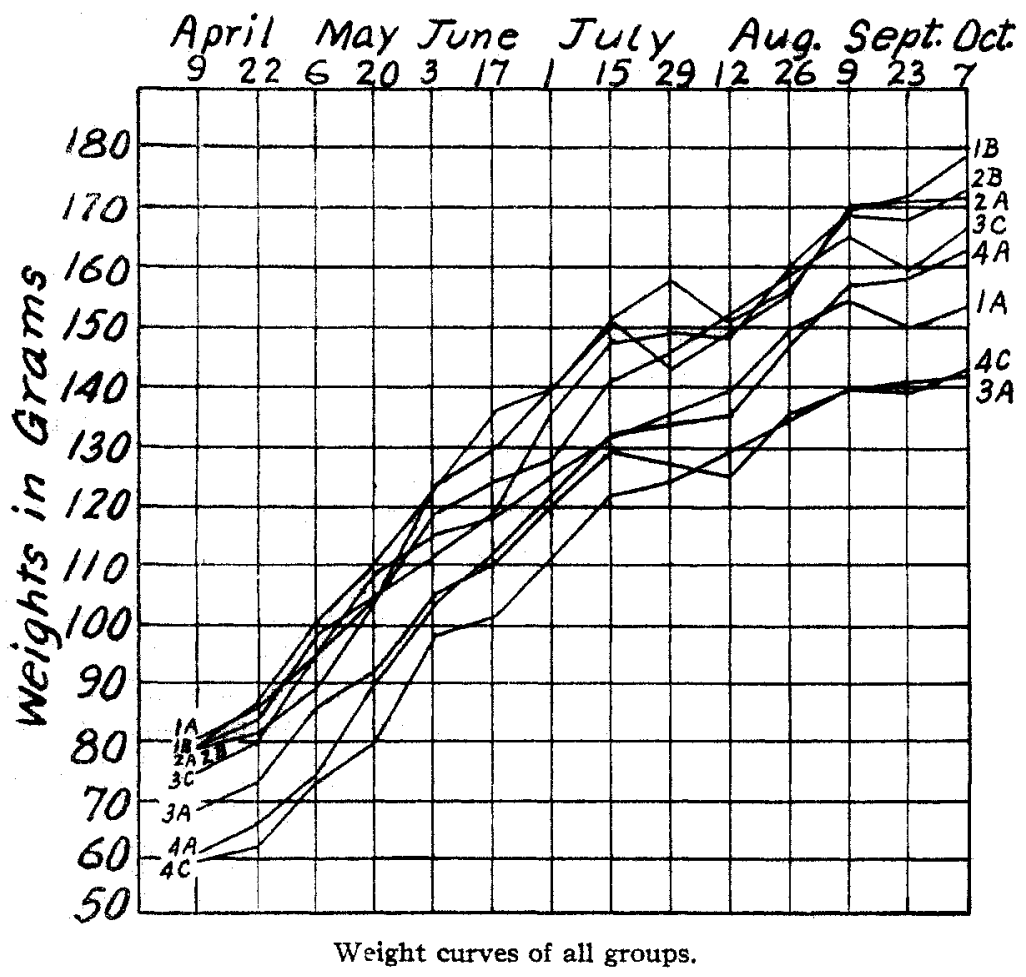

case is the weight of young after birth included in the weights. The results show that weight increased at practically the same rate in the various groups. 
TABLE II.

Summary of Chief Observations, April 8th to October 7 th.

\begin{tabular}{|c|c|c|c|c|c|c|c|c|c|c|c|c|}
\hline \multirow[b]{2}{*}{$\begin{array}{c}\text { Groups } \\
\text { of } \\
\text { rats. }\end{array}$} & \multicolumn{3}{|c|}{ April 9.} & \multirow[b]{2}{*}{ Died. } & \multirow{2}{*}{ Killed. } & \multirow{2}{*}{$\begin{array}{c}\text { Approx. } \\
\text { num- } \\
\text { ber of } \\
\text { young. }\end{array}$} & \multirow{2}{*}{$\begin{array}{c}\text { Young } \\
\text { born } \\
\text { Sept. } \\
8 \text { to } \\
\text { Oct. } 7 .\end{array}$} & \multicolumn{3}{|c|}{ October 7} & \multirow{2}{*}{$\begin{array}{c}\text { Increase } \\
\text { in wt. } \\
\% .\end{array}$} & \multirow{2}{*}{$\begin{array}{c}\text { Kinds } \\
\text { of bread } \\
\text { fed to } \\
\text { each group. }\end{array}$} \\
\hline & м. & $\mathbf{F}$. & $\begin{array}{c}\text { Av. wt. } \\
(\mathrm{g} .) .\end{array}$ & & & & & M. & F. & $\begin{array}{l}\text { Av. wt. } \\
(\mathrm{g} .) .\end{array}$ & & \\
\hline I $\mathbf{A}$ & II & 14 & 80 & 3 & 4 & 43 & 22 & 9 & 9 & 153.61 & 92.7 & Glucose \\
\hline I $\mathbf{B}$ & 14 & 10 & 79.2 & 6 & 4 & 5 & 3 & 9 & 6 & 178.66 & 125.5 & Sugar-free \\
\hline $2 \mathrm{~A}$ & 13 & Io & 79.1 & 5 & 4 & 38 & 18 & 7 & 7 & 171.07 & II 6.2 & Glucose \\
\hline $2 \mathrm{~B}$ & 12 & I3 & 78 & 7 & 4 & 30 & 12 & 8 & 6 & 173.21 & 122 & Sugar-free \\
\hline $3 \mathrm{~A}$ & I I & I4 & 68 & 3 & 4 & 57 & 30 & 7 & ro & 142.16 & 109 & Glucose \\
\hline $3 \mathrm{C}$ & 12 & 13 & 75.2 & 7 & 3 & 22 & 7 & 9 & 6 & 166.66 & 121.6 & Cane sugar \\
\hline $4 \mathrm{~A}$ & I2 & I3 & 60.4 & 5 & 4 & 53 & 15 & ro & 6 & 163.12 & 170 & Glucose \\
\hline $4 \mathrm{C}$ & 13 & 12 & 59.2 & 6 & 4 & - 54 & 32 & 6 & 9 & 143.33 & 142 & Cane sugar \\
\hline
\end{tabular}

Whenever possible, gross and microscopic examination was made of all rats that died spontaneously. On July 13 and again on August 23 two rats in each group, the subjects of the experiments on antibody production detailed on p. 7 , were killed and the organs examined. At the conclusion of the main experiment all the surviving animals were killed and examined. The results of the gross and microscopic examination did not differ in the case of any group from those in the other groups and no changes attributable to diet were found. Practically all deviations from the normal standards resulted from infection and involved mostly the lungs.

\section{Experiments on Antibody Production.}

In order to test the power of the rats fed on glucose bread, as compared with those fed on the other kinds of bread, to produce antibodies, two special experiments were made. The particular antibody studied in this case is the antibody against the red corpuscles of the sheep. The reason for using the antibody against sheep corpuscles for this experiment was that its course and amount in the rat are known from previous work, thus providing a basis for comparison.

As stated two experiments of this kind were made; namely, on July 7 and August 16. On each occasion two rats from each group were injected in the abdominal cavity with $5 \mathrm{cc}$. of a ro\% suspension of sheep blood per kilo of weight of rat. These rats were killed 6 days later and the amount of the antibody in question determined in the usual way. One injected rat Group ${ }_{3} \mathrm{C}$ died of pneumonia August 22.

The results are shown in Table III; the figures give the highest dilution of the blood serum of the rats in which the action of the antibody against sheep corpuscles could be detected.

The table shows that the rats fed on glucose bread and the rats fed on the other kinds of bread produced about the same amounts of antibody, and these amounts correspond very well to the amount ordinarily 
produced by rats injected the same way but living under the usual laboratory conditions. ${ }^{1}$

Table III.-Showing Amount of Antrbody to Shemp Corpuscles in Rats INIECTED WITH SHEEP BLOOD.

\begin{tabular}{|c|c|c|c|c|c|}
\hline \multirow{2}{*}{$\begin{array}{l}\text { Groups, } \\
\text { "IA" }\end{array}$} & \multicolumn{2}{|c|}{$\begin{array}{l}\text { Rats injected July } 6 . \\
\text { Tested July } 13 .\end{array}$} & \multicolumn{2}{|c|}{$\begin{array}{l}\text { Rats injected Aug. } 16 . \\
\text { Tested Aug. 23. }\end{array}$} & \multirow{2}{*}{$\begin{array}{l}\text { Kind of } \\
\text { bread fed to } \\
\text { each group. } \\
\text { Glucose }\end{array}$} \\
\hline & 24567 & 24567 & 12288 & I2288 & \\
\hline IB & 6 I 44 & 12288 & 12288 & 12288 & Sugar-free \\
\hline $2 A$ & I 536 & 24567 & 12288 & 6144 & Glucose \\
\hline $2 \mathbf{B}$ & 24567 & I 2288 & I 2288 & 24567 & Sugar-free \\
\hline $3 \mathrm{~A}$ & $245^{67}$ & I 2288 & 24567 & $245^{67}$ & Glucose \\
\hline${ }_{3} \mathrm{C}$ & I 2288 & I 2288 & 2 & 12288 & Cane sugar \\
\hline $4 A$ & I 2288 & I 2288 & 3072 & I 2288 & Glucose \\
\hline${ }_{4} \mathrm{C}$ & 6144 & 24567 & $6 \mathrm{r} 44$ & 12288 & Cane sugar \\
\hline
\end{tabular}

The results indicate that the power to produce antibodies is not diminished in rats fed as in this experiment, and permits the inference that glucose as here given does not reduce the resistance to infection.

\section{Discussion of the Results.}

The summary of the principal observations shows that the number of deaths from infections are about the same in the glucose fed and the control groups.

The percentage increase in the body weight is for the groups fed on glucose bread $122 \%$; on plain bread, $123.5 \%$; on cane sugar bread, $131.8 \%$. For some reason the number of young born in the glucose fed groups was larger than in the other groups and this fact probably accounts for the slightly lower rate of growth in the former.

The value of commercial glucose as food depends (I) on the extent to which the $d$-glucose and the dextrins are absorbed from the digestive tract and oxidized in the body; (2) on the absence of deleterious byproducts or contaminations in the glucose; and (3) on its palatability.

Our experiments do not show to what extent the glucose is absorbed and oxidized, as the rats were given as much food as they would eat, and this was probably more than the minimum required for growth and maintenance. Recently Sansom and Woodyatt ${ }^{3}$ have shown that in dogs with phlorhizin glucosuria the percentage of commercial glucose (per os) appearing as blood sugar is but slightly less than on feeding equal amounts of pure dextrose. The physiological literature gives no support to the view that the products of acid hydrolysis of starch are essentially

' See Hektoen, "The Formation of Antibodies in Rats Fed on Pure Vegetable Proteins"' (Osborne-Mendel Stunting Food), J. Infect, Dis., r5, 279 (1914).

2 Died of pneumonia.

${ }^{3} J$. Biol. Chem., 24, 13 (1916). 
different from the products of enzyme hydrolysis of starch. In the absence of definite experiments to the contrary one is therefore justified in concluding that the greater part of the dextrins and the dextrose in commercial glucose are utilized in the carbohydrate metabolism of the body.

In regard to the question of deleterious by-products and contaminations our experiments seem conclusive. There is practically no difference in the rate of growth, in resistance to infection, and in immune reaction in the glucose fed and the control rats. Postmortem examination revealed no lesion that could be traced to the diet in any of the groups. It should be pointed out, in this connection, that the quantity of glucose consumed per day by each rat was really considerable, namely, $2.5 \mathrm{~g}$. to $3.5 \mathrm{~g}$. per kilo body-weight, covering a period of about one-sixth of the total span of life of the rat. A parallel test on a group of persons weighing each 60 kilos and living sixty years on the average would mean a daily consumption of $150-200 \mathrm{~g}$. commercial glucose per day for Io years.

When the processes of manufacture are properly safeguarded deleterious admixtures in glucose from impurities in the chemicals employed are excluded. The sole remaining source of possible injurious by-products appear to be the acid hydrolysis of minute trace of proteins retained with the starch. However, there is no evidence that traces of such hydrolyzed proteins would be injurious when fed by mouth. On the contrary, it is well known that the products of acid hydrolysis of proteins are utilized in the protein metabolism of the body, even to the degree of maintenance of nitrogen equilibrium under certain conditions.

Table IV.-Tarle of average Weigets.

\begin{tabular}{|c|c|c|c|c|c|c|c|c|}
\hline Date. & $1 \mathrm{~A}$. & $1 \mathrm{~B}$ & $2 \mathrm{~A}$ & $2 \mathrm{~B}$. & $3 \mathrm{~A}$. & $3 \mathrm{C}$ & & $4 \mathrm{C}$. \\
\hline April $9 . . . \ldots$ & $\begin{array}{l}80 \\
86,28\end{array}$ & $\begin{array}{l}79.2 \\
84.2\end{array}$ & $\begin{array}{l}79.1 \\
86.52\end{array}$ & $\begin{array}{l}78 \\
82\end{array}$ & $\begin{array}{l}68 \\
73.2\end{array}$ & $\begin{array}{l}75.2 \\
79.6\end{array}$ & $\begin{array}{l}60.4 \\
66\end{array}$ & $\begin{array}{l}59.2 \\
62.4\end{array}$ \\
\hline May $6 \ldots . .$. & 95.6 & 97.83 & 100.87 & 89 & 86 & 95.8 & 74.17 & 73 \\
\hline May $20 . . . .$. & 108 & 105 & IIO & 104.73 & $92^{\circ}$ & 104.8 & 89.83 & \\
\hline June $3 \ldots \ldots$ & $\mathrm{II5.6}$ & I 10.86 & 123 & $123 \cdot 15$ & IO5 & 119.79 & 104.34 & 98.12 \\
\hline June $17 \ldots .$. & xI 7.56 & 118 & 136 & 129.42 & I IO & 124.16 & 112.6 & 101.73 \\
\hline July . ...... & 126.4 & 135.78 & I 39.47 & 138.94 & 120.8 & 127.91 & 121.95 & 110.86 \\
\hline July $x_{5} \ldots \ldots$ & 131.76 & 147.05 & I50. 47 & 151.88 & 129.13 & $14 \mathrm{I} \cdot 5^{2}$ & 133.09 & 122.1 \\
\hline July $29 \ldots \ldots$ & I35 & 148.88 & 143.33 & 157 & 127.4 & 145.75 & 134 & 124 \\
\hline Aug. $12 \ldots \ldots$ & 139.5 & 147.64 & $I 48.23$ & 150.58 & 125.9 & 151.66 & 135.5 & 129.16 \\
\hline Aug. $26 \ldots .$. & 149.44 & 160 & 156.33 & 156.66 & I 34.47 & 158.75 & $\mathrm{r} 47.77$ & I35 \\
\hline Sept. $9 \ldots \ldots$ & $\mathrm{r}_{54.88}$ & 169.33 & 170 & 168.57 & $\mathrm{r} 38.68$ & 165.62 & r 56.76 & 139.37 \\
\hline Sept. $23 \ldots .$. & 150 & 172.06 & $170.7 \mathrm{I}$ & 167.85 & 140.05 & 159.62 & 158.23 & 138.66 \\
\hline Oct. $7 \ldots \ldots \ldots$ & $\mathrm{r} 53.6 \mathrm{I}$ & 178.66 & $\times 7 \times .07$ & 173.21 & I42. I6 & 166.66 & 163.12 & 143.33 \\
\hline
\end{tabular}

The palatability of a food is a factor in its food value in relation to appetite and appetite secretion of gastric juice. In the case of sugar 
mixtures or syrups, palatability is essentially a question of degree of sweetness and character of flavor. It is well known that in equal concentrations $d$-glucose does not taste as sweet as cane sugar. However, the degree of sweetness and the character of the flavor preferred in a given food varies with the individual. The factor of palatability does not enter in the use of glucose in bakery products and confections, where the taste and flavor are determined by other ingredients.

\section{Summary and Conclusions.}

The addition of commercial glucose in the amounts of about $2.5 \mathrm{~g}$. to $3.5 \mathrm{~g}$. per kilo body weight per day to the diet of white rats for a period of six months has no abnormal influence on the animals, either favorable or unfavorable, as determined by the rate of growth fecundity, immunity reactions, and the condition of the organs.

As both the glucose fed and the control groups of rats were kept on a liberal diet throughout the observation period, the experiment does not show to what extent the commercial glucose was actually absorbed and oxidized, but in the quantities fed the commercial glucose certainly has no injurious effects.

Chicago, ILL.

[CONTRIBUTION FROM NORTHWESTERN UNIVERSITY MEDICAL, SCHOOL.]

\section{A SIMPLE CELL FOR THE DETERMANATION OF HYDROGEN ION CONCENTRATION.}

BY J. H. LoNG.

Received February 28, 1916.

Since the importance of the determination of $\mathrm{H}$ ion concentration has been recognized in so many fields of research there has been no end of suggestions as to types of cells assumed to have distinct advantages for the purpose in this or that direction. While, theoretically at least, the use of two hydrogen electrodes, the electrode in the liquid under investigation balanced against the similar electrode in a liquid of known ion concentration, is logically the simplest and most direct arrangement for the observation in hand, most attention has recently been given to the combination made up of one hydrogen electrode in the liquid plus a known calomel electrode. The advantage in this case is found mainly in the fact that the experiment requires the preparation of only one side of the cell, the calomel electrode being constant. In practical work, therefore, the double hydrogen electrode scheme has been largely abandoned, especially in physiological researches.

In cells constructed in part of the calomel electrode the recent types involve the recognition of the principles brought out in the researches of 